\title{
The application of the integrated production assets management system in the Polish Mining Group Inc.
}

\author{
Leszek Doległo, Jan Zdziebko \\ Polish Mining Group Inc. - Head Office, Poland
}

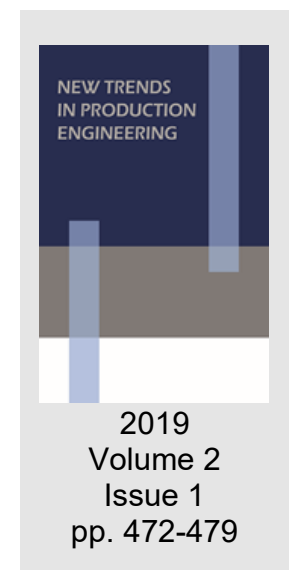

Date of submission to the Editor: 05/2019

Date of acceptance by the Editor: 08/2019

\section{INTRODUCTION}

The changing market situation, growing competition, requires mining companies to make swift and accurate decisions concerning the current activities but also taking into consideration the dynamics in the changes of the internal and external areas (Hąbek and Biały, 2017).

In the Mines, Motions, Plants of the Polish Mining Group Inc. the management of the production assets is supported by multiple IT solutions dedicated directly to domain areas involved in coal mining, as well as to the local area, assisting the main activity of the Group. Foreign customers buying coal make higher and higher quality requirements which must be met by commercial coal, at the same time ensuring competitive prices concerning the imported coal and other energy sources in terms of quality as well as economic viability of its mining and cleaning.

Meeting these expectations required PMG Inc. to adopt a systematic approach in terms of planning, monitoring, and accounting of the production process, as well as running the procedures involving the implementation of various cuttingedge solutions into the industrial practice.

The modern approach to managing production systems relates to the necessity to integrate modules and applications, thus ensuring reliable information, which then can be used while making production and management decisions (Pałucha, 2012). The growing pace of introducing new solutions in the broadly understood IT area points to the stronger connections between the issues of automation, control, and computer tools supporting technological and management processes. Computerization begins to dominate among innovative solutions introduced in the mining sector. It is essential to stay competitive in today's market, and in many areas, it is indispensable for mining companies to survive. Computing more and more data has become common practice. Therefore, it is necessary to implement the next stage of mining computerization, which means creating a technical analysis system based on Big Data technology (Kozłowski and Wojtas, 2018). The required 
characteristics, which should be aimed at in Big Data systems, are connected just as much with complexity as scalability. Apart from that, it should be not only efficient and effective in terms of using the resources, but also clear and easy to use (Marz et al., 2016).

\section{STANDARDIZATION OF TECHNICAL REQUIREMENTS FOR OBTAINING MEANS OF PRODUCTION}

To ensure the unification of the obtained means of production, the standardization of the technical requirements necessary in initiating tender procedures has been introduced for the selected groups of machines/devices. The unified technical requirements involve 29 items presented in Table 1.

Table 1 Presentation of the groups of production means covered by the standardization of technical requirements

\begin{tabular}{|c|l|c|l|}
\hline 1 & Pressure aggregates & 16 & Pumps in technological line \\
\hline 2 & 3.3 kV longwall shearer equipment & 17 & Submersible pumps \\
\hline 3 & Manoeuvring tractors & 18 & Frequency converters \\
\hline 4 & Battery manoeuvring tractors & 19 & Light scraper conveyors \\
\hline 5 & Suspended combustion tractors & 20 & Fiber optics welders \\
\hline 6 & Lease of pump units & 21 & Compressors \\
\hline 7 & Turnstiles & 22 & Compact stations \\
\hline 8 & Battery track locomotives & 23 & Transformer stations \\
\hline 9 & Combustion track locomotives & 24 & Ventilation sluices \\
\hline 10 & Dusters & 25 & Refrigeration and air-conditioning units \\
\hline 11 & Belt feeders without feeders & 26 & Dust removal devices \\
\hline 12 & Belt feeders with feeders & 27 & Pipe ventilators \\
\hline 13 & 6kV distribution fields & 28 & Cars, containers, platforms \\
\hline 14 & Mineral substances pumps & 29 & Transport units, cabins, break trucks \\
\hline 15 & Pumps outside technological line & & \\
\hline
\end{tabular}

Obtaining the scale effect in the standardization of machines/devices should be a continuous process, geared towards improving the procedures connected with the production process by incorporating further groups for which technical requirements have been set. Successful implementation of standardization would not be possible without engaging computer support, improving the activities connected with planning purchases, and preparing aggregated compilations. For this purpose, the site of the Office for Managing Production Assets has been used, which works on the SharePoint platform, on which a subsite was created to collect the needs connected with obtaining means of production from Mines, Motions, and Plants.

The implemented solution considerably shortened the process of collecting individual needs from Mines, Motions, and Plants, their analysis in terms of the standardization in progress, and preparing an application form to initiate the tender procedure. The central purchase needs, registration platform, gives the full control over technical requirements made available for those who register, and if some modifications need to be introduced, this operation is carried out by the staff in the Group's Head Office for all the branches of PMG Inc. 


\begin{tabular}{|c|c|c|c|c|}
\hline Biblioteki & \multirow{2}{*}{$\begin{array}{r}\square \text { Tyр } \\
\square\end{array}$} & Nazwa & $\square$ Typ & Nazwa \\
\hline Dokumentacja & & ROW-JAN & 밀 & WT - Ciagniki manewrowe \\
\hline Instrukcja obstugi & $\square$ & ROW-CHW & 삡] & $\begin{array}{l}\text { WT - Ciagniki spalinowe podwieszane } \\
\text { WT - Podajniki taśmowe bez podawarek }\end{array}$ \\
\hline \multirow{2}{*}{ Listy } & $\square$ & ROW-MAR & 힉 & WT - Podajniki taśmowe z podawarkami \\
\hline & $\square$ & ROW-RYD & 삑 & WT - Stacje kompaktowe \\
\hline 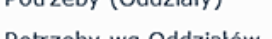 & 凩 & RUD-BIE & 밈 & WT - Stacje transformatorowe \\
\hline $\begin{array}{l}\text { Potrzeby wg Oddziałów } \\
\text { (Centrala) }\end{array}$ & 品 r r r & RUD-HAL & (2) & WT - Przenośniki zgrzeblowe lekkie \\
\hline \multirow{2}{*}{$\begin{array}{l}\text { Potrzeby cała lista } \\
\text { (Centrala) }\end{array}$} & 曰 & RUD-POK & 삘 & $\begin{array}{l}\text { WT - Agregaty disnieniowe } \\
\text { WT - Wentylatory lutniowe }\end{array}$ \\
\hline & $\square$ & PZ--PIA & 삑 & WT - śluzy wentylacyjne \\
\hline \multirow{8}{*}{ 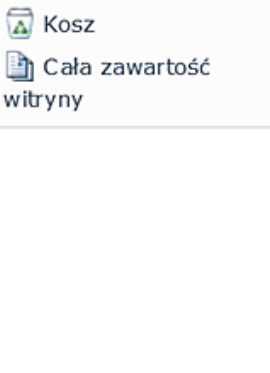 } & $\square$ & PZ--ZIE & 떱 & $\begin{array}{l}\text { WT - Opylacze } \\
\text { WT - Urzadzenia chłodnicze i klimatyczne }\end{array}$ \\
\hline & $\square$ & KWK-BOL & 맘 & WT - Sprężarki \\
\hline & $\square$ & KWK-SOS & 미 & WT - Pompy poza daagiem techndogicznym \\
\hline & $\square$ & KWK-MUR & 절 & WT - Aparatura na 3,3kV do zasilania kompleksów ścianowych \\
\hline & $\square$ & KWK-MYS & 밉 & $\begin{array}{l}\text { WT - Lokomotywy akumulatorowe torowe } \\
\text { WT - Pompy w dagu technologicznym }\end{array}$ \\
\hline & $\square$ & KWK-WUJ & 国 & WT - Pompy zatapialne \\
\hline & $\square$ & OD-ZGRI & 미 & WT - Dżerżawa zespołów pompowych \\
\hline & $\square$ & $O D--Z P E$ & ⿶凵] & WT - Ciagniki manewrowe akumulatorowe \\
\hline
\end{tabular}

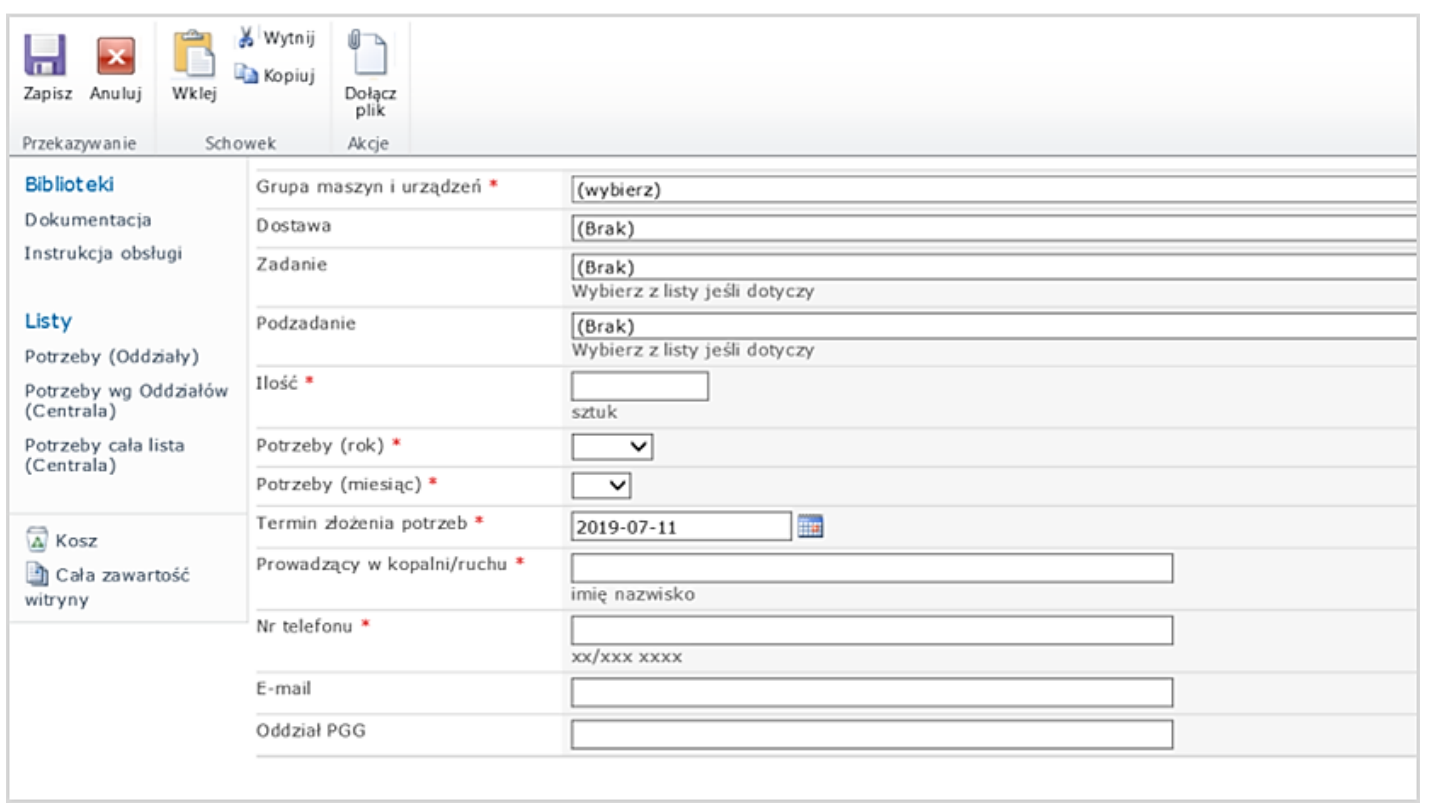

Fig. 1 The view of sample forms which are used to register the needs according to standard technical requirements, where:

1 - libraries of PMG Inc. branches, 2 - technical requirements, 3 - a form for registering needs.

\section{ELECTRONIC IDENTIFICATION OF FIXED ASSETS}

Effective management of the means of production requires that their identification is permanent and unambiguous, which can be achieved by using RFID (Radio Frequency Identification) technology in marking machines/devices, their parts, and components.

The solution provides a lasting, electronic record system allowing efficient management of production means, registration of their working performance, compiling analyses, as well, as periodic stocktaking. By monitoring the change of place of use, condition, and phase of management, it is possible to optimize their use (Website). The nameplates on machines and devices are exposed to wear and tear/damages resulting from exploitation in the mining environment 
and using an additional passive ID will introduce a unique identification record stored in databases.
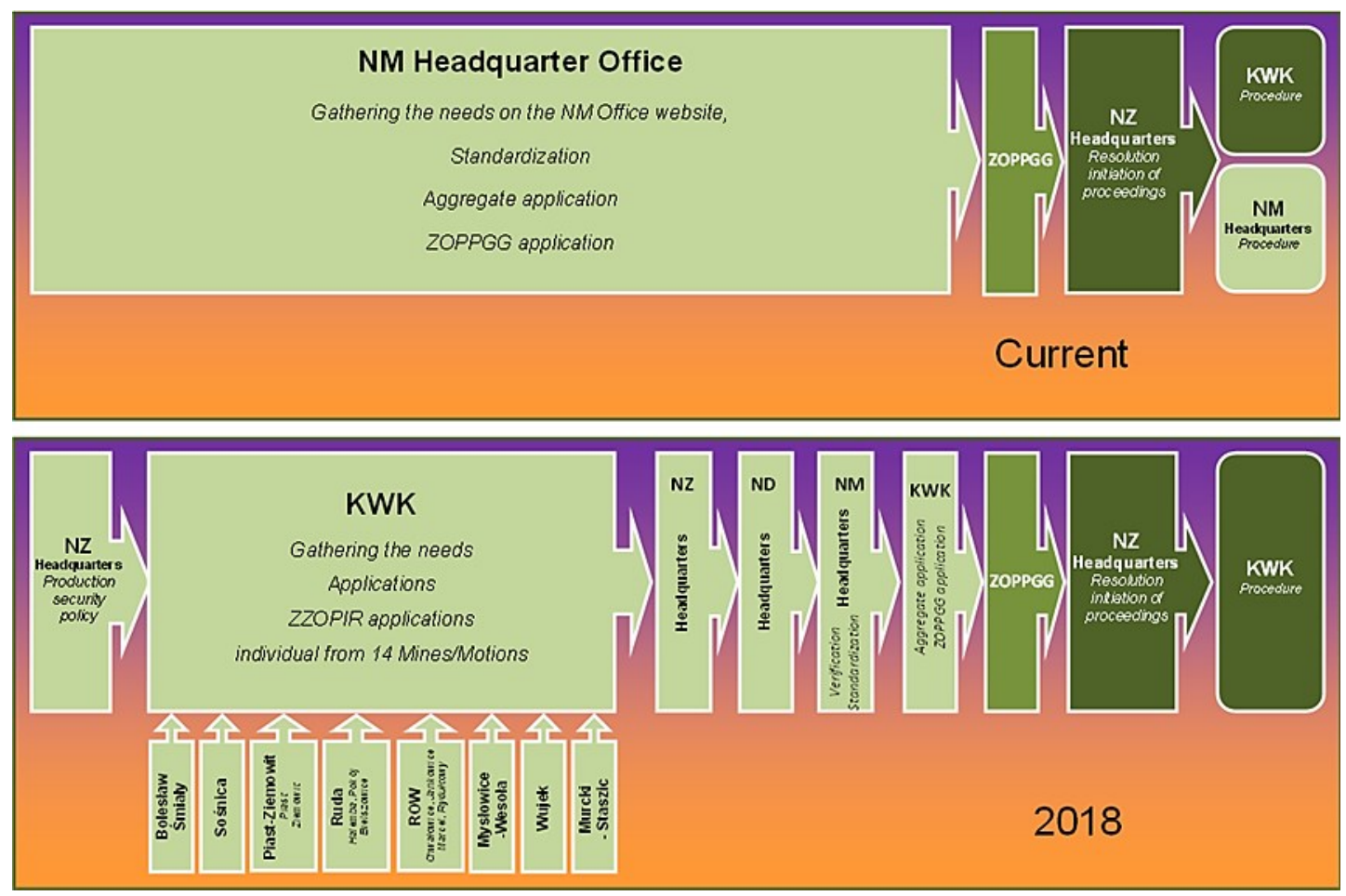

Fig. 2 The comparison of the current and the previous workflow of investment application form for purchasing the selected groups of machines and devices

In PMG Inc. branches, the process of marking the means of production with passive transponders is carried out by using gluing and welding technology. This year it is also planned to use transponders fixed using stainless steel bands. It will be dedicated mainly to those means of production which are small or have shapes unsuitable for the currently used methods of fixing.
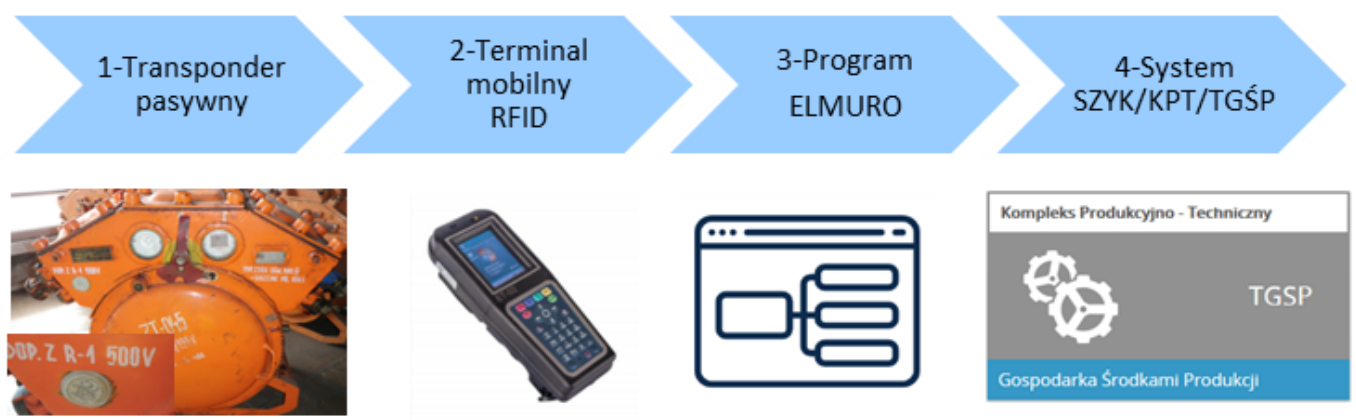

Fig. 3 Schematic presentation of the electronic identification of means of production, where: 1 - Passive transponder fixed on the housing, 2 - Mobile terminal for reading the data from the transponder, 3 - ELMURO program, in which the tasks to be carried out on the terminal are prepared, as well as collecting machines/devices, their parts and components,

4 - TGSP Module/System as the base of means of production ensuring two-way communication with other modules and programs 


\section{COOPERATION OF DOMAIN AREAS INVOLVED IN PRODUCTION ASSETS MANAGEMENT}

Making business decisions by the management of the Group requires expertise not only in economy and finances but also in industry and technology, including internal units and their surroundings. Continuous monitoring of the entered data and regular reporting should meet the current demands of the information recipients (Fornalczyk et al., 2008).

An essential aspect of the mines' activities is adjusting the running operations to all the legal requirements and supervising the area covered by machines and devices monitoring. To complete the specified tasks and reach the targets, close cooperation of all organizational units in a mine is essential (Hąbek and Biały, 2017).

Designing and optimizing production process demands a sophisticated analysis of the interconnected time relations, geological, mining, technical and organizational parameters as well as quality requirements for commercial coal. Making use of the available data resources in terms of allocating production assets involved in completing mining works calls for introducing new IT solutions allowing to carry out calculations when facing complex designing problems (Brzychczy et al., 2015).

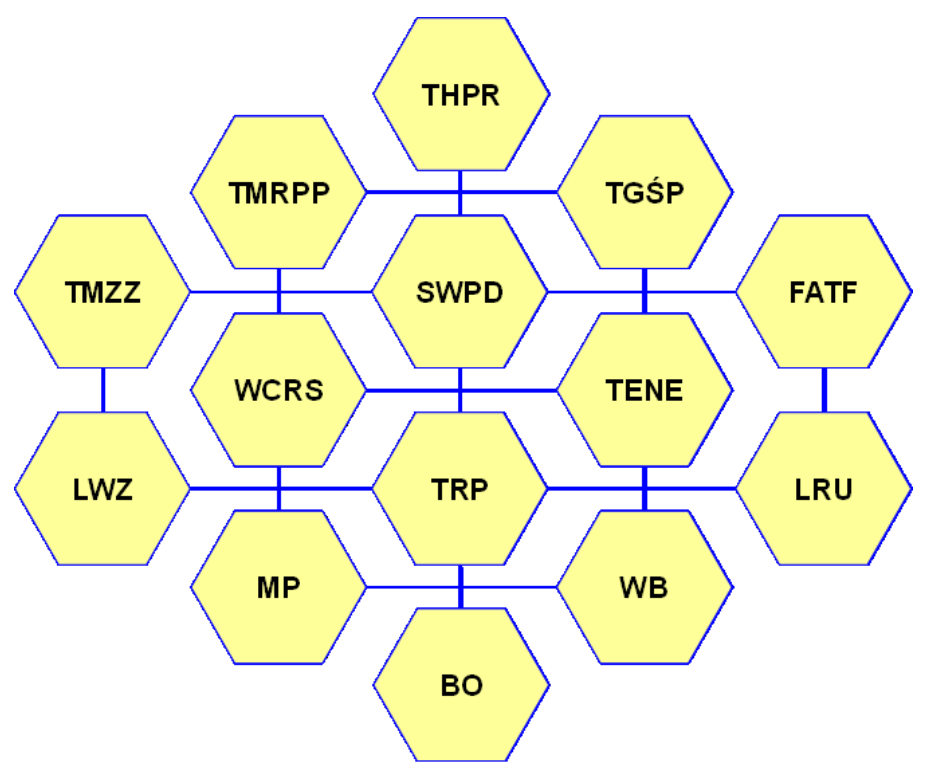

Fig. 3 Systems/modules/programs involved in production means management in PMG Inc., where: THPR - Scheduling Production, TMRPP2 - Monitoring and Reporting Production Processes, TGŚP - Managing Means of Production, TMZZ2 - Tasks Management, SWPD - Dispatcher Work Support System, FATF - Fixed and Financial Assets,

WCRS - Structural-Organizational File, TENE - Record and Media Settlement, LWZ - Purchases Support, TRP - Production Settlement, LRU - Contracts Register, MP - Monitoring Longwall and Drift Faces, WB - Industry Websites, BO - Data Warehouse

A crucial part in production data is played by the Dispatcher Work Support System, which collects the data directly from the sensors controlling technological process and elements assisting that process. It also works closely with the systems controlling and monitoring the parameters responsible for safety and working conditions on the mining sites. The visualization in 
dispatching systems is done through individual and large-scale dynamic synoptic boards (Utikal, 2014).

In PMG Inc., a project has been running for some time now to integrate systems, modules, and programs involving production means present in various domain processes.

In the activities carried out, an effort has been made to provide accuracy of the same type of data presented in various IT resources. Because of a complex network of relations, it would be difficult to describe all the areas shown in Figure 3. Therefore only a few sample solutions used in PMG Inc. have been presented. Planning equipment for longwall and frontal units WCRS/TMZZ/THPR/TGŚP. Periodic timetables for longwalls and face along with their equipment, cover two primary periods: two-year one and six-year one. The disposable machine equipment which is allocated to mining sites planned for future years is closely related to the exploration periods for faces and longwalls presented in the timetables. A change in the opening or closing date of mining sites in the timetables automatically triggers off a change in the allocated equipment. The mechanisms controlling the accuracy of data, operating in the modules, make sure that the user does not input incorrect data during a periodic modification of the timetables. For the equipment which is to be obtained for future locations (longwall, drift) a solution in TGŚP module has been introduced allowing to plan machines/devices which are not in stock at PMG Inc. but already feature in the timetables under specific parameters, although with no specified producer, who will be selected during the tender procedure.

\begin{tabular}{|c|c|c|c|c|}
\hline \multicolumn{5}{|c|}{$\begin{array}{l}\text { Wyposażenie do pozyskania } \\
\text { w okresie od: } 2019 \text { VI do: } 2021 \text { XII }\end{array}$} \\
\hline Rodzaj maszyny wg TGSP & $\begin{array}{c}\text { Wyposazerie } \\
\text { typ wg TGSP hb gupa wg TGSP }\end{array}$ & Forma pozyskania & Element planu - pierwsze wyrobisko & Data rozp. \\
\hline \multicolumn{5}{|l|}{ Kombajny ścianowe } \\
\hline & klasy $710 \mathrm{~kW}$ & pozyskarie & ściana 373a $(209 / 2)$ & 2020-06-01 06:00:00 \\
\hline & klasy $710 \mathrm{~kW}$ & pozyskanie & ściena $372 a(209 / 2)$ & $2020-08-0306: 00: 00$ \\
\hline & klesy $710 \mathrm{~kW}$ & pozyskanie & ściena $429(207 / 0)$ & $2021-09-0106: 00: 00$ \\
\hline & Razem szt.: 3 & & & \\
\hline & klasy $1500 \mathrm{~kW}$ & pozyskanie & sciana 390 a $(209 / 0)$ & $2019-06-1106: 00: 00$ \\
\hline & Razem szt.: 1 & & & \\
\hline
\end{tabular}

Fig. 4 Sample report for one Motion with longwall shearers planned to obtain in the period from June 2019 to December 2021

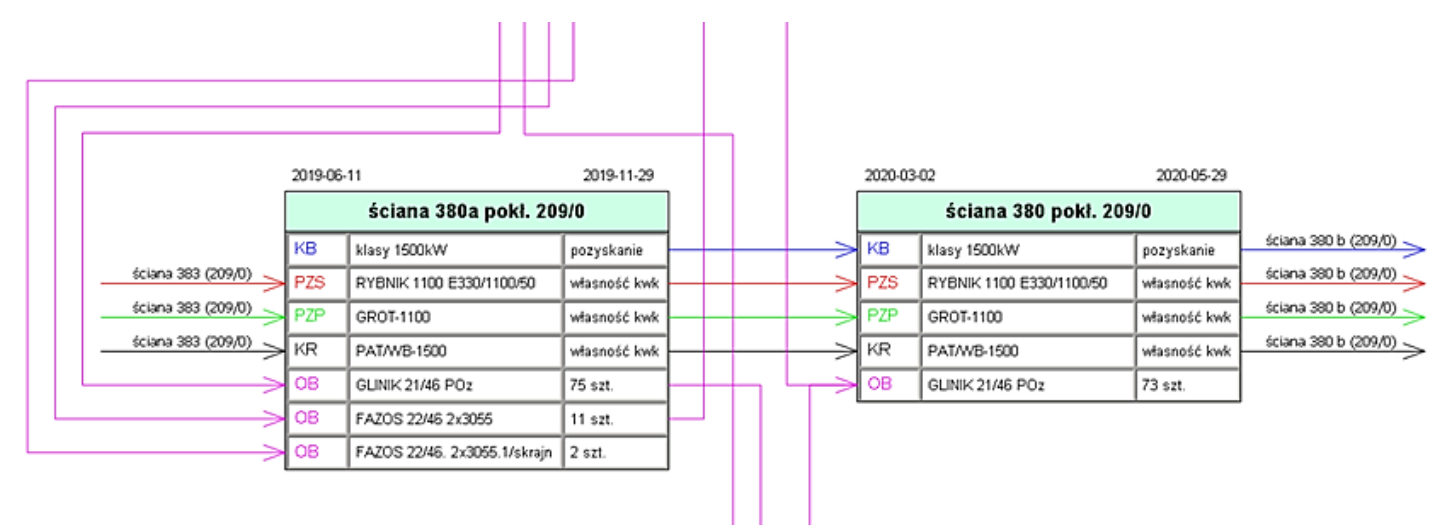

Fig. 5 A section of a block timetable presenting longwall 380 a, for which it has been planned to obtain a $1500 \mathrm{~kW}$ longwall shearer 


\section{ELECTRONIC DOCUMENT FLOW}

Within the structure of the Group, several processes are going on, influencing each other, or completing their tasks individually. Until recently in PMG Inc., the workflow connected with the activity: „Receipt of fixed asset at PMG Inc.” - OT, "Change in the location of using fixed asset” - MT, „Relocation of fixed assets between PMG Inc. branches" - PTW, was executed by means of paper forms approved by the participants of the flow with a traditional stamp and signature. This created a situation in which the document approval time was mainly dependent on the availability of the people appointed for the approval flow. The growing demands for effective production assets management led to the introduction of new standards based on electronic documents, in which the personnel department verifies the participants in the process. Such a procedure ensured that the information and the people appointed to approve electronic documents were by the currently held position. Another goal achieved by the implementation of electronic workflow is the possibility to report the current state of task completion, occupancy, and efficiency at every stage of information flow. Based on the observations carried out a new functionality has been introduced, the so-called "silent approval", which guaranteed the elimination of timeconsuming situations in which electronic MT documents were held up by people participating in the approval flow, thus ensuring reliable information on the location of the fixed assets in use in the domain modules of SZYK2 system and Business Objects Data Warehouse.

The new functionality works at three successive stages:

STAGE 1 - TRANSFERRING - on the first day of the month following the reporting month (calendardate) the program will check if there are any MT documents issued but not forwarded to the approval flow - such documents will be transferred to the next stage.

STAGE 2 - RECEIVING - on the third day of the month following the reporting month (calendardate) the program will check if there are any MT documents pending the take-over approval - such documents will be approved and transferred to the next stage.

STAGE 3 - CONTROLLING - on the sixth day following the reporting month (calendardate) the program will check if there are any MT documents which have not been verified - such documents will automatically be approved and forwarded to the accounting department which will either book or reject the documents according to the rules in force so far.

All MT documents approvals automatically made in TGŚP are monitored and presented by the program as well as sent to mailboxes of the people appointed in the electronic workflow of the MT document.

\section{CONCLUSION}

The management of means of production at the Polish Mining Group Inc. is targeted at a system approach supported by IT solutions guaranteeing to maintain the assets necessary for completing the scheduled production tasks. 
Current verification is conducted of the technical condition of machines and devices with a view to their further use.

The machines and devices fit for further use (included in the deployment plan) which, according to the current production timetables, have not been used in a short period of time, made up the necessary operating reserve, underwent overhauls, modernization and servicing with a view to preparing them for work at further longwall units. Machines not deployed over more extended periods were relocated to other mines of the Group, in response to the current needs and possibilities.

Fixed assets items in the form of machines and devices unused in the current production activities and those which are not scheduled to be used in the future, as well as the machines and devices no longer fit for use, will be gradually recycled, and the regained scrap metal will be sold in accordance with the existing rules at the Group.

\title{
REFERENCES
}

Brzychczy E., Napieraj A., Sukiennik M. (2015). Modelowanie i optymalizacja wydobycia w kopalniach węgla kamiennego z wykorzystaniem struktur gridowych. Przegląd Górniczy No. 8/2015 (in polish).

Fornalczyk A., Choroszczak J., Mikulec M. (2008). Restrukturyzacja górnictwa węgla kamiennego Poltext Publishing house, Warsaw, (in polish)

Hąbek P., Biały W. (2017). Zintegrowany system zarządzania w kopalni - zadania, cele. Monografia AGH, Kraków 2017.

Kozłowski A., Wojtas P. (2018). Zintegrowany system zarządzania produkcją i bezpieczeństwem SILESIA w kontekście nowych wyzwań związanych z ideą przemysłu 4.0.Mining Engineering, No. 1/2018.

Marz N., Warren J. (2016). Big Data - Najlepsze praktyki budowy skalowalnych systemów obsługi danych w czasie rzeczywistym. Helion Publishing House, Gliwice (in polish).

Pałucha K. (2012). Zarządzanie systemami produkcyjnymi - nowe wyzwania. TNOiK Publishing house, Katowice. (in polish)

Utikal J. (2014). Elementy systemów dyspozytorskich w procesie technologicznym w podziemnych zakładach górniczych. „Śląsk” Publishing house, Katowice, (in polish).

Website:

https://www.elektronika.elsta.pl/kompetencje/zarzadzanie-srodkamitrwalymi-z-wykorzystaniem-technologii-rfid/

\begin{abstract}
.
The management of the production assets in the Polish Mining Group Inc. is geared towards achieving strategic aims through the unification of the obtained machines/devices, their practical use while maintaining them in the proper technical condition, adhering to proper maintenance-renovation procedures, reserves optimization as well as final recycling with no re-use in the production cycle. The following paper presents the functioning of the IT support in the production assets management, geared towards the integration with other areas of technical and economic activities of the Group. The modular structure of the integrated IT system makes it possible to gradually implement the successive solutions functioning within the Group as well as in the surrounding local areas, ensuring the suitability to the current needs of the organization and the system users.
\end{abstract}

Keywords: production management, mining machinery, IT systems 